\title{
Insulin Sensitivity, Serum Lipids, and Systemic Inflammatory Markers in School-Aged Obese and Nonobese Children
}

\author{
Jinkwan Kim, ${ }^{1}$ Rakesh Bhattacharjee, ${ }^{2}$ Leila Kheirandish-Gozal, ${ }^{1}$ Abdelnaby Khalyfa, ${ }^{1}$ \\ Oscar Sans Capdevila, ${ }^{3}$ Riva Tauman, ${ }^{4}$ and David Gozal ${ }^{1}$ \\ ${ }^{1}$ Department of Pediatrics, Comer Children's Hospital, The University of Chicago, Suite K-160, 5721, Maryland Avenue, \\ MC 8000, Chicago, IL 60637, USA \\ ${ }^{2}$ Division of Sleep and Respiratory Medicine, Department of Pediatrics, The Hospital for Sick Children, University of Toronto, \\ Toronto, ON, Canada M5G 1 X8 \\ ${ }^{3}$ Pediatric Sleep Unit, Division of Neurophysiology, Department of Neurology, Hospital Sant Joan de Déu, 08950 Barcelona, Spain \\ ${ }^{4}$ Dana Children's Hospital, Tel-Aviv University School of Medicine, Tel-Aviv 64239, Israel
}

Correspondence should be addressed to David Gozal, dgozal@uchicago.edu

Received 29 June 2010; Revised 31 October 2010; Accepted 24 December 2010

Academic Editor: Tai Fai Fok

Copyright ( $) 2010$ Jinkwan Kim et al. This is an open access article distributed under the Creative Commons Attribution License, which permits unrestricted use, distribution, and reproduction in any medium, provided the original work is properly cited.

\begin{abstract}
The impact of obesity as a systemic low-grade inflammatory process has only partially been explored. To this effect, 704 community-based school-aged children (354 obese children and 350 age-, gender-, and ethnicity-matched controls) were recruited and underwent assessment of plasma levels of fasting insulin and glucose, lipids, and a variety of proinflammatory mediators that are associated with cardiometabolic dysfunction. Obese children were at higher risk for abnormal HOMA and cholesterol levels. Furthermore, BMI $z$ score, HOMA, and LDL/HDL ratio strongly correlated with levels of certain inflammatory mediators. Taken together, obesity in children is not only associated with insulin resistance and hyperlipidemia, but is accompanied by increased, yet variable, expression of markers of systemic inflammation. Future community-based intervention and phenotype correlational studies on childhood obesity will require inclusion of expanded panels of inflammatory biomarkers to provide a comprehensive assessment of risk on specific obesity-related morbidities.
\end{abstract}

\section{Introduction}

Childhood obesity is a serious and progressively increasing public health problem that has reached epidemic proportions and in the United States disproportionately affects low-income and minority children [1-3]. Metabolic and cardiovascular complications of obesity in childhood, while less common than in adulthood, may nevertheless include insulin resistance and type 2 diabetes. Body mass index (BMI) tracks from childhood to adulthood and as such, overweight and obese children are at greater risk of developing not only hypertension, metabolic, and cardiovascular diseases, but also asthma and sleep apnea in later life [4-8].

In adults, obesity is associated with increases in systemic inflammatory markers, as evidenced by studies documenting the association of BMI and visceral obesity with circulating levels of cytokines and acute-phase reactants [9-11]. In children, the presence of obesity also appears to be associated with increased levels of high-sensitivity CRP (hsCRP) [12], as well as other inflammatory mediators [13-17], that promote the development of endothelial and metabolic dysfunction [18-21]. A recent review on this topic [22] concluded that although there appears to be sufficient evidence to support the existence of an association between obesity and increased hsCRP along with decreased adiponectin levels, the circulating levels found in the majority of the studies published in the literature are generally within the normative range, and could therefore underestimate the concentrations of these mediators at the tissue level. Tam et al. further recommended additional studies measuring IL- 6 and TNF$\alpha$, as well as other interleukins and chemokines in young children [22].

Concurrent with such understanding of the published literature and in agreement with the recommendations by Tam and colleagues [22], we hypothesized that by examining the concentration of fasting morning plasma inflammatory 
mediators obtained from community-based obese children, we would expect to find variable expression of specific inflammatory mediators in this cohort that have previously been shown to increase the cardiovascular and/or metabolic disease risk.

\section{Methods}

2.1. Subjects. The study was approved by the University of Louisville Human Research Committee, and informed consent was obtained from the legal caregiver of each participant. Consecutive children between the ages of 5 to 8 years attending public schools in Jefferson County, Louisville, KY, were invited to participate in the study, after they underwent a school-based health screening, which included height and weight measurements. Based on such screening, children were identified when their BMI $z$ score was $\geq 1.65$ and age- (within 3-6 months), gender-, ethnicity-, and area-of-residence-matched children with BMI $z$ scores $<1.65$ were then identified and recruited to serve as controls. Of note, all children were otherwise healthy, were recruited from the community via the Jefferson County Public School Health Screening Program, and were representative of the demographic characteristics of the general population of the city of Louisville (http://ksdc.louisville.edu/sdc/census2000/ cityprofiles/LouisvilleDP.pdf). Children were excluded if they had known diabetes or prediabetes (http://www.diabetes .org/pre-diabetes/pre-diabetes-symptoms.jsp), any defined genetic abnormality or underlying systemic disease including hypertension (as defined by a systolic or diastolic blood pressure exceeding the 95th percentile for age, gender, and height using population data obtained by the National Heart Lung and Blood Institute), or if they were within a month from any acute infectious process.

2.2. Anthropometry. To verify the school-health screening initial reports, children were weighed using a calibrated scale to the nearest $0.1 \mathrm{~kg}$ and height (to $0.1 \mathrm{~cm}$ ) was measured with a stadiometer (Holtain, Crymych, UK). Body mass index (BMI) was calculated and BMI z-score was computed using CDC 2000 growth standards (http://www.cdc.gov/ growthcharts/) and online software (http://www.cdc.gov/ epiinfo/). A BMI $z$ score $\geq 1.65$ was considered as fulfilling the criteria for obesity.

2.3. Blood Based Assays. Fasting blood samples were drawn by venipuncture in the morning. Blood samples were immediately centrifuged, and plasma was frozen at $-80^{\circ} \mathrm{C}$ until assay. Plasma insulin levels were measured using a commercially available radioimmunoassay kit (Coat-ACount Insulin; Diagnostic Products Inc). This method has a detection level of $1.2 \mu \mathrm{IU} / \mathrm{mL}$ and exhibits linear behavior up to $350 \mu \mathrm{IU} / \mathrm{mL}$, with intra-assay and interassay coefficients of variability of $3.1 \%$ and $4.9 \%$, respectively. Plasma glucose level was measured using a commercial kit based on the hexokinase-glucose-6-phosphate dehydrogenase method (Flex Reagent Cartridges; Dade Behring, Newark, DE). Insulin resistance was assessed using a widely validated mathematical formula, the homeostasis model assessment (HOMA) equation (fasting insulin $\times$ fasting glucose/22.5) [23].

Plasma hsCRP levels were measured within 2-3 hours after collection using the Flex Reagent Cartridge (Date Behring, Newark, DE). This method has a detection level of $0.05 \mathrm{mg} / \mathrm{dL}$ and exhibits linear behavior up to $255 \mathrm{mg} / \mathrm{dL}$, with intra-assay and interassay coefficients of variability of $9 \%$ and $18 \%$, respectively, for hsCRP. Serum lipids including total cholesterol, high-density lipoprotein (HDL) cholesterol, calculated low-density lipoprotein cholesterol (LDL), and triglycerides (TG) were also assessed using Flex Reagent Cartridges (Dade Behring).

Plasma IL-6, IL-20, monocyte chemotactic protein (MCP), retinol-binding protein 4 (RBP4), and tumor necrosis factor (TNF- $\alpha$ ) levels were measured using commercial ELISA kits (R\&D systems, Minneapolis, MN). Plasma apolipoprotein B (ApoB), myeloid-related protein (MRP) $8 / 14$, and macrophage inhibitory factor (MIF) levels were also measured using commercial ELISA kits (ALPCO Diagnostics, Salem, NH) following the manufacturer's instructions. Circulating levels of ICAM-1 and P-selectin were measured with commercially available kits (R\&D System, Abington, UK). For ICAM-1, the sensitivity was $0.35 \mathrm{ng} / \mathrm{mL}$ and the intra- and interassay coefficients of variation were 2.5 and $1.8 \%$, respectively. For P-selectin, the sensitivity was $0.5 \mathrm{ng} / \mathrm{mL}$ and the intra- and interassay coefficients of variation were 3.6 and $6.9 \%$, respectively. All assays were performed in duplicate, and a calibration curve was included in each assay.

2.4. Statistical Analysis. Data were expressed as mean \pm SD. Significant differences within groups were analyzed using ANOVA followed by post-hoc tests with Bonferroni corrections for multiple comparisons for continuous variables and chi-square tests for categorical variables. Spearman's correlation analyses were conducted to examine potential associations between BMI and plasma concentrations of the various inflammatory mediators. Statistical analyses were performed using SPSS software (version 16.0; SPPS Inc., Chicago, Ill.). All $P$ values reported are 2-tailed with statistical significance set at $<.05$.

\section{Results}

A total of 354 obese children and 350 age-, gender-, and ethnicity-matched nonobese children were recruited between May 2004 and October 2008. The demographic characteristics of this cohort are shown in Table 1 and are virtually identical to the published demographics of the city of Louisville, Kentucky. It should be pointed out that not every child could have all of the inflammatory markers assayed, as dictated by the limited amounts of plasma, such that, the number of inflammatory marker assays varied from one child to another.

As anticipated, obese children had higher HOMA values, indicative of insulin resistance, and also exhibited higher LDL, VLDL, and TG levels and lower HDL concentrations compared to nonobese children (Table 1). 
TABle 1: Demographic characteristics of obese and nonobese children.

\begin{tabular}{|c|c|c|c|}
\hline & $\begin{array}{c}\text { Obese } \\
(\mathrm{BMI} Z \geq 1.65)\end{array}$ & $\begin{array}{c}\text { Nonobese } \\
(\mathrm{BMI} Z<1.65)\end{array}$ & $P$-value* \\
\hline Age (years) & $\begin{array}{l}7.1 \pm 0.4 \\
(n=354)\end{array}$ & $\begin{array}{l}7.1 \pm 0.4 \\
(n=350)\end{array}$ & \\
\hline $\begin{array}{l}\text { Gender } \\
(\% \text { male })\end{array}$ & 51.2 & 51.1 & \\
\hline \multicolumn{4}{|l|}{ Ethnicity } \\
\hline $\begin{array}{l}\text { White } \\
\text { Caucasian \% }(n)\end{array}$ & $\begin{array}{c}77.9 \\
(n=277)\end{array}$ & $\begin{array}{c}78.0 \\
(n=273)\end{array}$ & \\
\hline $\begin{array}{l}\text { African- } \\
\text { American \% } \\
(n)\end{array}$ & $\begin{array}{c}18.1 \\
(n=64)\end{array}$ & $\begin{array}{c}18.0 \\
(n=63)\end{array}$ & \\
\hline BMI $z$ score & $2.21 \pm 0.14$ & $1.06 \pm 0.21$ & $<.00001$ \\
\hline $\begin{array}{l}\text { Systolic Blood } \\
\text { Pressure } \\
(\mathrm{mmHg})\end{array}$ & $\begin{array}{c}112.4 \pm 9.7 \\
(n=354)\end{array}$ & $\begin{array}{c}107.1 \pm 10.9 \\
(n=350)\end{array}$ & $<.01$ \\
\hline $\begin{array}{l}\text { Diastolic blood } \\
\text { pressure } \\
(\mathrm{mmHg})\end{array}$ & $\begin{array}{c}67.1 \pm 8.2 \\
(n=354)\end{array}$ & $\begin{array}{l}62.7 \pm 7.9 \\
(n=350)\end{array}$ & $<.01$ \\
\hline Triglycerides & $84.1 \pm 5.1$ & $73.5 \pm 2.8$ & $<.001$ \\
\hline HDL & $42.5 \pm 1.8$ & $62.9 \pm 1.8$ & $<.00001$ \\
\hline VLDL & $19.1 \pm 1.3$ & $14.7 \pm 0.9$ & $<.001$ \\
\hline LDL & $98.7 \pm 2.9$ & $93.3 \pm 1.8$ & $<.001$ \\
\hline Glucose & $81.3 \pm 1.8$ & $78.2 \pm 1.7$ & $<.04$ \\
\hline Insulin & $14.9 \pm 1.7$ & $6.7 \pm 1.0$ & $<.0001$ \\
\hline HOMA-IR & $2.3 \pm 0.3$ & $1.2 \pm 0.3$ & $<.0001$ \\
\hline
\end{tabular}

* Statistical significance determined using ANOVA test.

Obese children also had significantly higher levels of hsCRP, IL-6, MRP 8/14, P-selectin, ICAM-1, IL-20, RBP4, MIF, and TNF- $\alpha$ compared to nonobese children (Table 2). Only ApoB and MCP showed similar levels among the 2 groups. Among the obese children, 57\% showed one, 34\% two, $19 \%$ three, and $15 \%$ four or more cardiometabolic biomarkers with elevated plasma levels.

Regression analyses between each of the inflammatory markers and actual BMI or BMI $z$ score revealed significant correlations for the majority of these markers (Table 3). In addition, hsCRP was also significantly associated with IL-6 $(r=0.35 ; n=145 ; P<.01)$, MRP $8 / 14(r=0.67 ; n=$ 236; $P<.001)$, and with TNF- $\alpha(r=0.46 ; n=122 ; P<$ $.01)$. Furthermore, hsCRP was also positively correlated with ICAM-1 $(r=0.29 ; n=98 ; P<.03)$ and with RBP4 $(r=$ $0.32 ; n=80 ; P<.05)$. Similarly, significant correlations emerged between RBP4, MRP 8/14, TNF- $\alpha$, hsCRP, and HOMA (Table 3). In addition MRP 8/14, IL-6, hsCRP, MIF, P-selectin, ICAM-1, and TNF- $\alpha$ levels showed significant associations with LDL/HDL (Table 3).

\section{Discussion}

This study shows that systemic inflammatory processes are activated in otherwise asymptomatic, community-dwelling, obese, and school-age prepubertal children. Interestingly, the
TABLE 2: Fasting morning plasma concentrations of inflammatory biomarkers in obese and nonobese children.

\begin{tabular}{|c|c|c|c|}
\hline & $\begin{array}{c}\text { Obese } \\
(\mathrm{BMI} Z \geq 1.65)\end{array}$ & $\begin{array}{c}\text { Nonobese } \\
(\mathrm{BMI} Z<1.65)\end{array}$ & $P$-values* \\
\hline $\begin{array}{l}\text { MRP 8/14 } \\
\text { (ug/mL) }\end{array}$ & $\begin{array}{l}1.5 \pm 0.9 \\
(n=128)\end{array}$ & $\begin{array}{r}0.9 \pm 0.8 \\
(n=176)\end{array}$ & .0001 \\
\hline $\begin{array}{l}\text { Apo B } \\
(\mathrm{mg} / \mathrm{dL})\end{array}$ & $\begin{array}{c}77.8 \pm 19.6 \\
(n=65)\end{array}$ & $\begin{array}{c}73.7 \pm 16.3 \\
(n=51)\end{array}$ & .233 \\
\hline $\begin{array}{l}\text { MCP } \\
(\mathrm{pg} / \mathrm{mL})\end{array}$ & $\begin{array}{c}132.0 \pm 29.6 \\
(n=77)\end{array}$ & $\begin{array}{c}120.1 \pm 18.8 \\
(n=68)\end{array}$ & .494 \\
\hline $\begin{array}{l}\mathrm{RBP} 4 \\
(\mathrm{ng} / \mathrm{mL})\end{array}$ & $\begin{array}{c}33.4 \pm 16.3 \\
(n=80)\end{array}$ & $\begin{array}{l}18.2 \pm 14.0 \\
(n=80)\end{array}$ & .01 \\
\hline $\begin{array}{l}\text { IL-20 } \\
(\mathrm{pg} / \mathrm{mL})\end{array}$ & $\begin{array}{l}4.0 \pm 5.4 \\
(n=67)\end{array}$ & $\begin{array}{l}2.3 \pm 4.5 \\
(n=44)\end{array}$ & .02 \\
\hline IL-6 (pg/mL) & $\begin{array}{l}1.8 \pm 0.9 \\
(n=132)\end{array}$ & $\begin{array}{l}1.0 \pm 0.6 \\
(n=134)\end{array}$ & .01 \\
\hline $\begin{array}{l}\mathrm{MIF} \\
(\mathrm{pg} / \mathrm{mL})\end{array}$ & $\begin{array}{c}188.6 \pm 103.1 \\
\quad(n=132)\end{array}$ & $\begin{array}{c}131.7 \pm 86.4 \\
(n=106)\end{array}$ & .02 \\
\hline $\begin{array}{l}\text { hsCRP } \\
(\mathrm{mg} / \mathrm{dL})\end{array}$ & $\begin{array}{l}2.3 \pm 1.4 \\
(n=354)\end{array}$ & $\begin{array}{l}0.5 \pm 0.3 \\
(n=350)\end{array}$ & $<.0001$ \\
\hline $\begin{array}{l}\text { TNF- } \alpha \\
(\mathrm{pg} / \mathrm{mL})\end{array}$ & $\begin{array}{c}598.5 \pm 62.2 \\
\quad(n=172)\end{array}$ & $\begin{array}{c}317.3 \pm 42.2 \\
\quad(n=176)\end{array}$ & .0001 \\
\hline $\begin{array}{l}\text { P selectin } \\
(\mathrm{ng} / \mathrm{mL})\end{array}$ & $\begin{array}{c}94.3 \pm 22.2 \\
(n=56)\end{array}$ & $\begin{array}{c}37.7 \pm 12.9 \\
(n=90)\end{array}$ & .0001 \\
\hline $\begin{array}{l}\text { ICAM-1 } \\
(\mathrm{ng} / \mathrm{mL})\end{array}$ & $\begin{array}{c}397.4 \pm 83.5 \\
(n=56)\end{array}$ & $\begin{array}{c}247.4 \pm 53.5 \\
(n=90)\end{array}$ & .0001 \\
\hline
\end{tabular}

* Statistical significance determined using ANOVA test.

degree and nature of the activation of these inflammatory processes varied from child to child, and only a minority of obese children exhibited extensive derangements across multiple cardiometabolic inflammatory biomarkers. Furthermore, there were significant associations between specific subsets of the inflammatory markers and the degree of obesity, insulin resistance, or hyperlipidemia. However, while there was some degree of overlap among the inflammatory markers associated with each of these variables, the more remarkable finding was that even if a particular marker was elevated and correlated with end-organ dysfunction, this did not necessarily imply that all other markers were affected as well. The pathophysiology of end-organ morbidities that are traditionally perceived as resulting from the long-term effects of obesity on health has been postulated to involve low-grade activation of multiple pathways of inflammation. Based on the current understanding of the roles played by these inflammatory mediators, it becomes imperative to explore the role of genetic, environmental, and lifestyle influences on the modulation of the inflammatory responses in the context of obesity, and its consequences [24, 25]. Similarly, it will be critical to assess in the future the effect of interventions such as dietary changes and physical activity on the reversibility of these inflammatory responses and on the progression of obesity-related morbidities [26-30].

Before we discuss any further the potential implications of our findings, some technical and methodological approaches deserve comment. We selected a wide net array of known biomarkers for both cardiovascular and metabolic 
TABLE 3: Correlation coefficients between BMI and BMI $z$ score and plasma levels of several inflammatory markers in children.

\begin{tabular}{|c|c|c|c|c|}
\hline & $\begin{array}{c}\text { BMI } \\
r \text {-value }\end{array}$ & $\begin{array}{c}\text { BMI } z \text { score } \\
r \text {-value }\end{array}$ & $\begin{array}{l}\text { HOMA } \\
r \text {-value }\end{array}$ & $\begin{array}{c}\text { LDL/HDL ratio } \\
r \text {-value }\end{array}$ \\
\hline $\begin{array}{l}\text { MRP } 8 / 14(\mathrm{ug} / \mathrm{mL}) \\
(n=249)\end{array}$ & $0.354^{*}$ & $0.375^{*}$ & $0.332^{*}$ & $0.227^{*}$ \\
\hline $\begin{array}{l}\text { Apo B }(\mathrm{mg} / \mathrm{dL}) \\
(n=116)\end{array}$ & 0.143 & 0.160 & 0.02 & 0.10 \\
\hline $\begin{array}{l}\mathrm{MCP}(\mathrm{pg} / \mathrm{mL}) \\
(n=143)\end{array}$ & 0.00 & 0.00 & 0.00 & 0.12 \\
\hline $\begin{array}{l}\mathrm{RBP} 4(\mathrm{ng} / \mathrm{mL}) \\
(n=160)\end{array}$ & $0.213^{*}$ & $0.317^{*}$ & $0.376^{*}$ & 0.09 \\
\hline $\begin{array}{l}\mathrm{IL}-20(\mathrm{pg} / \mathrm{mL}) \\
(n=111)\end{array}$ & -0.054 & -0.036 & 0.01 & 0.03 \\
\hline $\begin{array}{l}\text { IL-6 }(\mathrm{pg} / \mathrm{mL}) \\
(n=266)\end{array}$ & $0.161^{*}$ & $0.177^{*}$ & $0.132^{*}$ & $0.134^{*}$ \\
\hline $\begin{array}{l}\operatorname{MIF}(\mathrm{pg} / \mathrm{mL}) \\
(n=108)\end{array}$ & 0.043 & 0.02 & $0.110^{*}$ & $0.176^{*}$ \\
\hline $\begin{array}{l}\text { hsCRP }(\mathrm{mg} / \mathrm{dL}) \\
(n=704)\end{array}$ & $0.472^{*}$ & $0.367^{*}$ & $0.276^{*}$ & $0.365^{*}$ \\
\hline $\begin{array}{l}\text { TNF- } \alpha(\mathrm{pg} / \mathrm{mL}) \\
(n=348)\end{array}$ & $0.298^{*}$ & $0.336^{*}$ & $0.187^{*}$ & $0.215^{*}$ \\
\hline $\begin{array}{l}\text { P selectin }(\mathrm{ng} / \mathrm{mL}) \\
(n=146)\end{array}$ & $0.310^{*}$ & $0.376^{*}$ & 0.087 & $0.387^{*}$ \\
\hline $\begin{array}{l}\text { ICAM-1 }(\mathrm{ng} / \mathrm{mL}) \\
(n=146)\end{array}$ & $0.254^{*}$ & $0.276^{*}$ & 0.104 & $0.413^{*}$ \\
\hline
\end{tabular}

In parenthesis in the number of observations for which data were available, ${ }^{*} P<.05$. Statistical significance determined using Spearman's correlational analysis.

dysfunction, in an attempt to characterize the variability and the potential associations of these markers in the context of pediatric obesity. However, since hsCRP has been extensively used in past studies, we aimed to include this measure in all children. We also restricted the age range of our cohort to a narrow time span that is associated with the initial 3 years of attendance in the public school system, a period during which changes in eating patterns are now well described [31-34]. We also selected our population based on a representative community sample for the city of Louisville, Kentucky, and identified this cohort in the school system itself, rather than using a clinical referral cohort. As such, we also selected a closely matching nonobese child, in the same school, to control for and all of the potential confounders that could be introduced in the process of cohort allocation. However, neither pubertal status nor the presence of hepatic steatosis was assessed.

Globally, the findings from this study indicate the presence of a substantial inflammatory burden in obese prepubertal children along with a high risk for insulin resistance and increased serum lipids. Therefore, our study is in close agreement with multiple other studies in children that have examined a selected number of inflammatory mediators in the context of obesity [12, 35-46]. Of note, in a study by Nagel and colleagues, these investigators did not find any evidence for a significant association between increased body weight in children and ApoB levels, and our current findings are in close concordance with such report in German children [44]. Similarly, our findings concur with the increased plasma levels of adhesion molecules in a pediatric overweight cohort from Mexico, suggesting evidence of endothelial dysfunction in a substantial proportion of obese children [47]. Of note, the inflammatory markers that were presently associated with either BMI, BMI $z$ score, HOMA, and hypercholesterolemia varied, suggesting different and coordinated biological roles for clusters of inflammatory modulators. Indeed, although there was some degree of overlap among the inflammatory markers and their respective significant associations, only a portion of the markers were correlated with any given end-organ dysfunction.

In summary, this study clearly shows that obesity in childhood carries a substantial inflammatory burden that is strongly, yet selectively, associated with specific functional alterations, such as insulin sensitivity or lipid homeostasis. With the emergence of multiplexed ELISA assays that exhibit improved sensitivities, we would advocate that future community-based intervention or correlational studies on childhood obesity [48] should explore more expansive panels of inflammatory markers along with functional phenotypes, and should also consider incorporation of genomic variance assessments using recently developed cardiovascular or metabolic gene-centric polymorphism arrays [49].

\section{Acknowledgments}

D. Gozal is supported by National Institutes of Health Grants no. HL-065270 and HL-086662. R. Bhattacharjee was supported by a fellowship from Jazz Pharmaceuticals. J. Kim and R. Bhattacharjee contributed equally to this paper.

\section{References}

[1] D. W. Haslam and W. P. T. James, "Obesity," Lancet, vol. 366, no. 9492, pp. 1197-1209, 2005.

[2] Y. Wang and M. A. Beydoun, "The obesity epidemic in the United States—gender, age, socioeconomic, racial/ethnic, and geographic characteristics: a systematic review and metaregression analysis," Epidemiologic Reviews, vol. 29, no. 1, pp. 6-28, 2007.

[3] C. L. Ogden, M. D. Carroll, and K. M. Flegal, "High body mass index for age among US children and adolescents, 2003-2006," Journal of the American Medical Association, vol. 299, no. 20, pp. 2401-2405, 2008.

[4] D. S. Freedman, D. A. Patel, S. R. Srinivasan et al., "The contribution of childhood obesity to adult carotid intimamedia thickness. The Bogalusa Heart Study," International Journal of Obesity, vol. 32, no. 5, pp. 749-756, 2008.

[5] D. S. Freedman, P. T. Katzmarzyk, W. H. Dietz, S. R. Srinivasan, and G. S. Berenson, "Relation of body mass index and skinfold thicknesses to cardiovascular disease risk factors in children. The Bogalusa Heart Study," American Journal of Clinical Nutrition, vol. 90, no. 1, pp. 210-216, 2009.

[6] D. S. Freedman, W. H. Dietz, S. R. Srinivasan, and G. S. Berenson, "Risk factors and adult body mass index among overweight children. The Bogalusa Heart Study," Pediatrics, vol. 123, no. 3, pp. 750-757, 2009.

[7] N. Mattsson, T. Rönnemaa, M. Juonala, J. S. A. Viikari, and O. T. Raitakari, "Childhood predictors of the metabolic 
syndrome in adulthood. The cardiovascular risk in Young Finns study," Annals of Medicine, vol. 40, no. 7, pp. 542-552, 2008.

[8] American Academy of Pediatrics, "Policy statement: prevention of pediatric overweight and obesity," Pediatrics, vol. 112, pp. 424-430, 2003.

[9] U. N. Das, "Is obesity an inflammatory condition?" Nutrition, vol. 17, no. 11-12, pp. 953-966, 2001.

[10] J. Sacheck, "Pediatric obesity: an inflammatory condition?" Journal of Parenteral and Enteral Nutrition, vol. 32, no. 6, pp. 633-637, 2008.

[11] C. Maffeis, D. Silvagni, R. Bonadonna, A. Grezzani, C. Banzato, and L. Tatò, "Fat cell size, insulin sensitivity, and inflammation in obese children," Journal of Pediatrics, vol. 151, no. 6, pp. 647-652, 2007.

[12] M. Visser, L. M. Bouter, G. M. McQuillan, M. H. Wener, and T. B. Harris, "Low-grade systemic inflammation in overweight children," Pediatrics, vol. 107, no. 1, p. E13, 2001.

[13] D. Nemet, P. Wang, T. Funahashi et al., "Adipocytokines, body composition, and fitness in children," Pediatric Research, vol. 53, no. 1, pp. 148-152, 2003.

[14] M. Halle, U. Korsten-Reck, B. Wolfarth, and A. Berg, "Lowgrade systemic inflammation in overweight children: impact of physical fitness," Exercise Immunology Review, vol. 10, pp. 66-74, 2004.

[15] F. S. Ezgü, A. Hasanoğlu, L. Tümer, F. Özbay, C. Aybay, and M. Gündüz, "Endothelial activation and inflammation in prepubertal obese Turkish children," Metabolism, vol. 54, no. 10, pp. 1384-1389, 2005.

[16] M. Juonala, J. S. A. Viikari, T. Rönnemaa, L. Taittonen, J. Marniemi, and O. T. Raitakari, "Childhood C-reactive protein in predicting CRP and carotid intima-media thickness in adulthood. The Cardiovascular Risk in Young Finns Study," Arteriosclerosis, Thrombosis, and Vascular Biology, vol. 26, no. 8, pp. 1883-1888, 2006.

[17] A. R. Brasil, R. C. Norton, M. B. Rossetti, E. Leão, and R. P. Mendes, "C-reactive protein as an indicator of low intensity inflammation in children and adolescents with and without obesity," Jornal de Pediatria, vol. 83, no. 5, pp. 477-480, 2007.

[18] A. Sbarbati, F. Osculati, D. Silvagni et al., "Obesity and inflammation: evidence for an elementary lesion," Pediatrics, vol. 117, no. 1, pp. 220-223, 2006.

[19] T. Reinehr, W. Kiess, G. De Sousa, B. Stoffel-Wagner, and R. Wunsch, "Intima media thickness in childhood obesity: relations to inflammatory marker, glucose metabolism, and blood pressure," Metabolism, vol. 55, no. 1, pp. 113-118, 2006.

[20] M. Valle Jiménez, R. M. Estepa, R. MA. M. Camacho, R. C. Estrada, F. G. Luna, and F. B. Guitarte, "Endothelial dysfunction is related to insulin resistance and inflammatory biomarker levels in obese prepubertal children," European Journal of Endocrinology, vol. 156, no. 4, pp. 497-502, 2007.

[21] S. Lee, F. Bacha, N. Gungor, and S. Arslanian, "Comparison of different definitions of pediatric metabolic syndrome: relation to abdominal adiposity, insulin resistance, adiponectin, and inflammatory biomarkers," Journal of Pediatrics, vol. 152, no. 2, pp. 177-184, 2008.

[22] C. S. Tam, K. Clément, L. A. Baur, and J. Tordjman, "Obesity and low-grade inflammation: a paediatric perspective," Obesity Reviews, vol. 11, no. 2, pp. 118-126, 2010.

[23] D. R. Matthews, J. P. Hosker, and A. S. Rudenski, "Homeostasis model assessment: insulin resistance and $\beta$-cell function from fasting plasma glucose and insulin concentrations in man," Diabetologia, vol. 28, no. 7, pp. 412-419, 1985.
[24] D. M. Stringer, E. A. C. Sellers, L. L. Burr, and C. G. Taylor, "Altered plasma adipokines and markers of oxidative stress suggest increased risk of cardiovascular disease in First Nation youth with obesity or type 2 diabetes mellitus," Pediatric Diabetes, vol. 10, no. 4, pp. 269-277, 2009.

[25] G. S. Berenson, "Cardiovascular risk begins in childhood. A time for action," American Journal of Preventive Medicine, vol. 37, supplement 1, pp. S1-S2, 2009.

[26] T. Reinehr, B. Stoffel-Wagner, C. L. Roth, and W. Andler, "High-sensitive C-reactive protein, tumor necrosis factor $\alpha$, and cardiovascular risk factors before and after weight loss in obese children," Metabolism, vol. 54, no. 9, pp. 1155-1161, 2005.

[27] N. E. Thomas and D. R. R. Williams, "Inflammatory factors, physical activity, and physical fitness in young people: review," Scandinavian Journal of Medicine and Science in Sports, vol. 18, no. 5, pp. 543-556, 2008.

[28] A. L. Carrel, J. J. McVean, R. R. Clark, S. E. Peterson, J. C. Eickhoff, and D. B. Allen, "School-based exercise improves fitness, body composition, insulin sensitivity, and markers of inflammation in non-obese children," Journal of Pediatric Endocrinology and Metabolism, vol. 22, no. 5, pp. 409-415, 2009.

[29] R. Kelishadi, M. Hashemi, N. Mohammadifard, S. Asgary, and N. Khavarian, "Association of changes in oxidative and proinflammatory states with changes in vascular function after a lifestyle modification trial among obese children," Clinical Chemistry, vol. 54, no. 1, pp. 147-153, 2008.

[30] A. A. Meyer, G. Kundt, U. Lenschow, P. Schuff-Werner, and W. Kienast, "Improvement of early vascular changes and cardiovascular risk factors in obese children after a sixmonth exercise program," Journal of the American College of Cardiology, vol. 48, no. 9, pp. 1865-1870, 2006.

[31] N. D. Ernst and E. Obarzanek, "Child health and nutrition: obesity and high blood cholesterol," Preventive Medicine, vol. 23, no. 4, pp. 427-436, 1994.

[32] B. M. Popkin and P. Gordon-Larsen, "The nutrition transition: worldwide obesity dynamics and their determinants," International Journal of Obesity, vol. 28, supplement 3, pp. S2S9, 2004.

[33] M. Chopra, S. Galbraith, and I. Darnton-Hill, "A global response to a global problem: the epidemic of overnutrition," Bulletin of the World Health Organization, vol. 80, no. 12, pp. 952-958, 2002.

[34] M. B. Zimmermann and I. Aeberli, "Dietary determinants of subclinical inflammation, dyslipidemia and components of the metabolic syndrome in overweight children: a review," International Journal of Obesity, vol. 32, supplement 6, pp. S11-S18, 2008.

[35] E. S. Ford, D. A. Galuska, C. Gillespie, J. C. Will, W. H. Giles, and W. H. Dietz, "C-reactive protein and body mass index in children: findings from the 3rd national health and nutrition examination survey, 1988-1994," Journal of Pediatrics, vol. 138, no. 4, pp. 486-492, 2001.

[36] D. G. Cook, M. A. Mendall, P. H. Whincup et al., "C-reactive protein concentration in children: relationship to adiposity and other cardiovascular risk factors," Atherosclerosis, vol. 149, no. 1, pp. 139-150, 2000.

[37] A. D. Aygun, S. Gungor, B. Ustundag, M. K. Gurgoze, and Y. Sen, "Proinflammatory cytokines and leptin are increased in serum of prepubertal obese children," Mediators of Inflammation, vol. 2005, no. 3, pp. 180-183, 2005.

[38] A. A. Meyer, G. Kundt, M. Steiner, P. Schuff-Werner, and W. Kienast, "Impaired flow-mediated vasodilation, carotid artery 
intima-media thickening, and elevated endothelial plasma markers in obese children: the impact of cardiovascular risk factors," Pediatrics, vol. 117, no. 5, pp. 1560-1567, 2006.

[39] S. D. De Ferranti, K. Gauvreau, D. S. Ludwig, J. W. Newburger, and N. Rifai, "Inflammation and changes in metabolic syndrome abnormalities in US adolescents: findings from the 1988-1994 and 1999-2000 National Health and Nutrition Examination Surveys," Clinical Chemistry, vol. 52, no. 7, pp. 1325-1330, 2006.

[40] E. V. Economou, A. V. Malamitsi-Puchner, C. P. Pitsavos, E. E. Kouskouni, I. Magaziotou-Elefsinioti, and G. Creatsas, "Lowgrade systemic inflammation profile, unrelated to homocysteinemia, in obese children," Mediators of Inflammation, vol. 2005, no. 6, pp. 337-342, 2005.

[41] G. Akinci, B. Akinci, S. Coskun, P. Bayindir, Z. Hekimsoy, and B. Özmen, "Evaluation of markers of inflammation, insulin resistance and endothelial dysfunction in children at risk for overweight," Hormones, vol. 7, no. 2, pp. 156-162, 2008.

[42] J. Y. Shin, S. Y. Kim, M. J. Jeung et al., "Serum adiponectin, Creactive protein and TNF- $\alpha$ levels in obese Korean children," Journal of Pediatric Endocrinology and Metabolism, vol. 21, no. 1, pp. 23-29, 2008.

[43] M. E. Atabek, "Obese related effects of inflammatory markers and insulin resistance on increased carotid intima-media thickness in pre-pubertal children," Atherosclerosis, vol. 200, no. 2, p. 446, 2008.

[44] G. Nagel, K. Rapp, M. Wabitsch et al., "Prevalence and cluster of cardiometabolic biomarkers in overweight and obese schoolchildren: results from a large survey in Southwest Germany," Clinical Chemistry, vol. 54, no. 2, pp. 317-325, 2008.

[45] J. R. Ruiz, F. B. Ortega, J. Warnberg, and M. Sjöström, “Associations of low-grade inflammation with physical activity, fitness and fatness in prepubertal children. The European Youth Heart Study," International Journal of Obesity, vol. 31, no. 10, pp. 1545-1551, 2007.

[46] S. Kapiotis, G. Holzer, G. Schaller et al., "A proinflammatory state is detectable in obese children and is accompanied by functional and morphological vascular changes," Arteriosclerosis, Thrombosis, and Vascular Biology, vol. 26, no. 11, pp. 25412546, 2006.

[47] A. E. Caballero, R. Bousquet-Santos, L. Robles-Osorio et al., "Overweight latino children and adolescents have marked endothelial dysfunction and subclinical vascular inflammation in association with excess body fat and insulin resistance," Diabetes Care, vol. 31, no. 3, pp. 576-582, 2008.

[48] C. A. Pratt, J. Stevens, and S. Daniels, "Childhood obesity prevention and treatment. Recommendations for future research," American Journal of Preventive Medicine, vol. 35, no. 3, pp. 249-252, 2008.

[49] B. J. Keating, S. Tischfield, S. S. Murray et al., "Concept, design and implementation of a cardiovascular gene-centric $50 \mathrm{~K}$ SNP array for large-scale genomic association studies," PLoS ONE, vol. 3, no. 10, article e3583, 2008. 


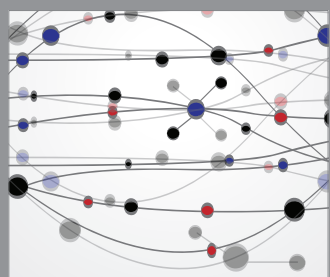

The Scientific World Journal
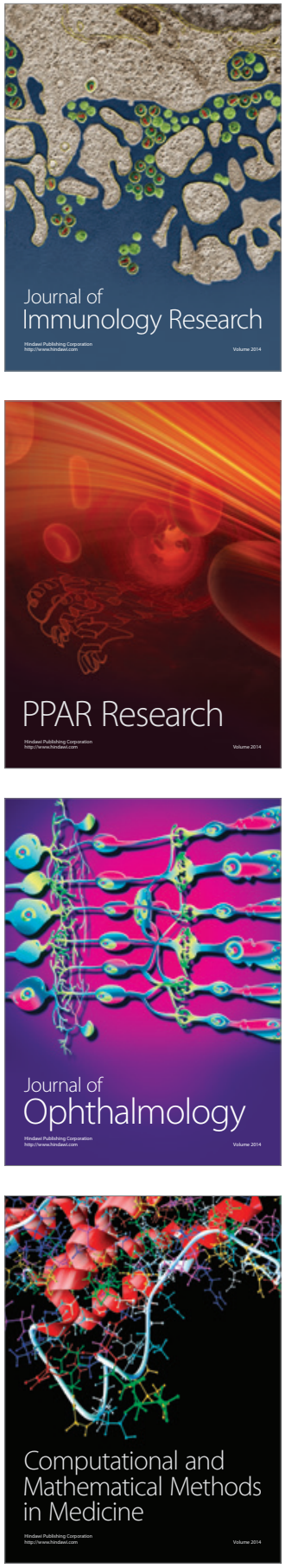

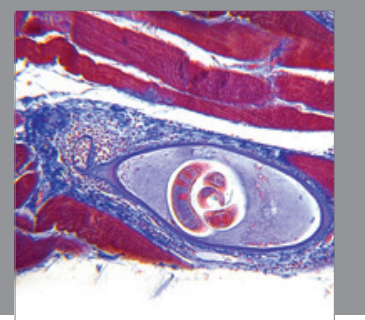

Gastroenterology

Research and Practice
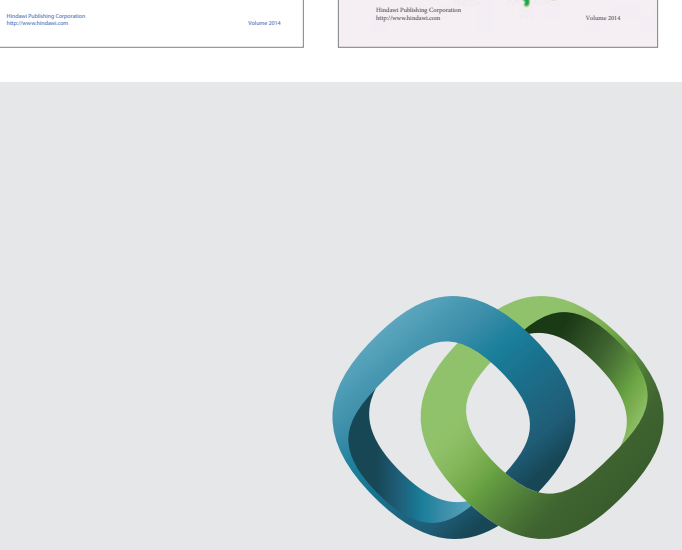

\section{Hindawi}

Submit your manuscripts at

http://www.hindawi.com
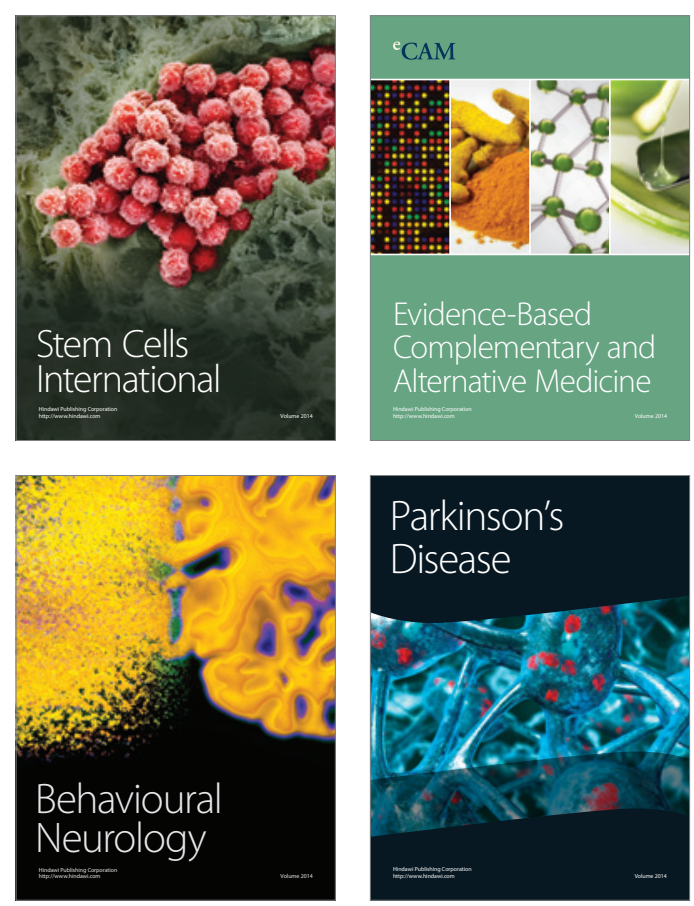

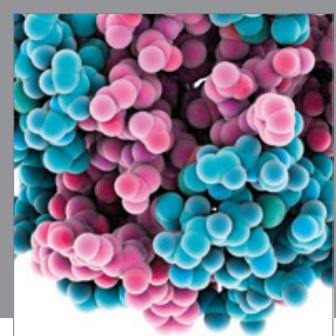

Journal of
Diabetes Research

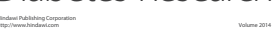

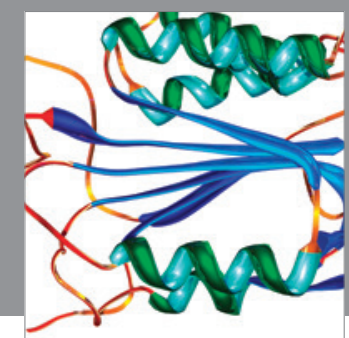

Disease Markers
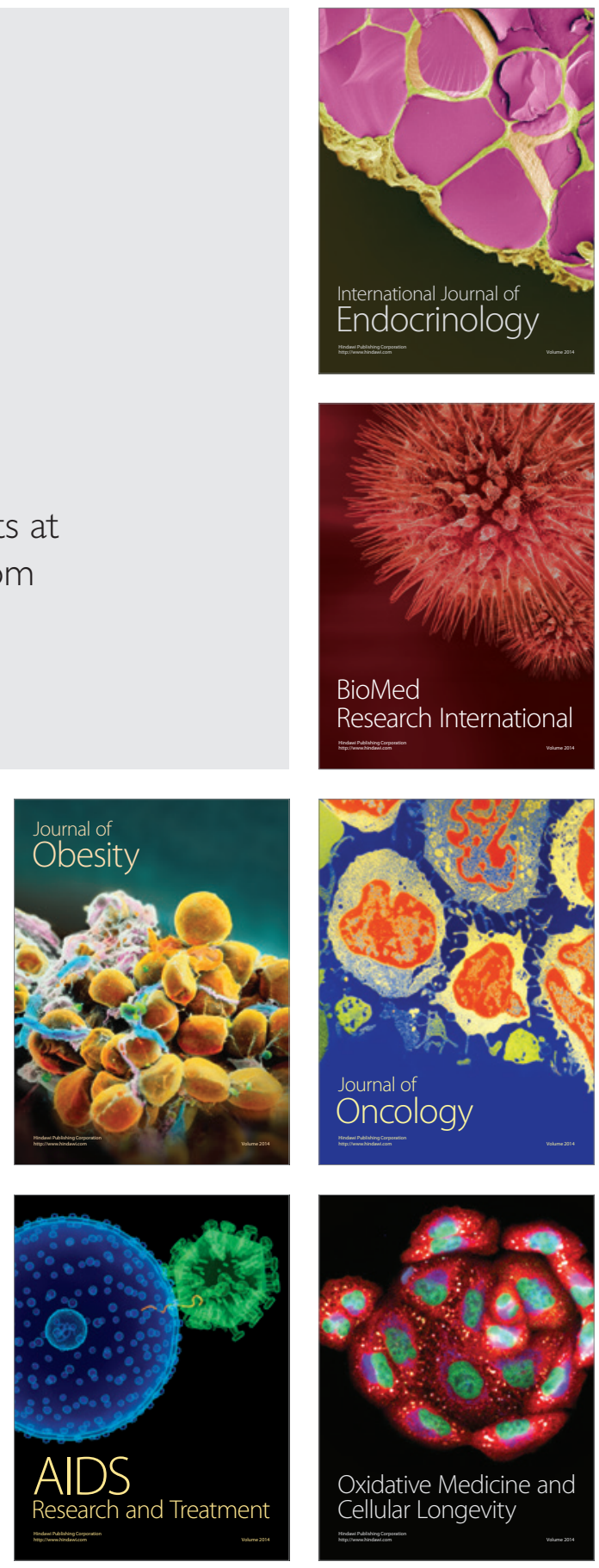